\title{
THE EFFECTS OF DIETARY INCLUSION OF DIFFERENT LEVELS OF FLAXSEED ON THE DIGESTIBILITY, GROWTH PERFORMANCE, BLOOD PARAMETERS AND FATTY ACID PROFILE IN GROWING NEW-ZEALAND WHITE (NZW) RABBITS
}

\author{
Sh. A. M. Ibrahim ${ }^{1}$; Y.A.A. El-Nomeary ${ }^{1}$; Fatma M. Salman ${ }^{1}$ and B.A. Bakry ${ }^{2}$ \\ ${ }^{1}$ Animal Production Department, National Research Centre, 33 El-Bohouth Street, P.O.:12622, Dokki, \\ Giza, Egypt. \\ ${ }^{2}$ Field Crops Research Department, National Research Centre, 33 El-Bohouth Street, P.O.: 12622, \\ Dokki, Giza, Egypt.
}

(Received 5/1/2021, accepted 3/2/2021)

\section{SUMMARY}

\begin{abstract}
A
total number of 60 male New-Zealand White (NZW) rabbits post-weaning was used to study the effect of the inclusion of three levels (4, 6 and $8 \%$ ) of flaxseed (FS) in the rabbit diet on nutrients digestibility, growth performance, blood parameters and fatty acid profile. Rabbits were distributed among 4 equal groups ( 3 replicates, 5 rabbits each). The $1^{\text {st }}$ group received the basal diet without FS. The other three groups $\left(2^{\text {nd }}, 3^{\text {rd }}\right.$ and $4^{\text {th }}$ ) received the basal diet with FS at levels 4,6 and $8 \%$, respectively. Rabbits were fed experimental diets for 8 weeks. Feeding diet contains FS at $6 \%$ level significantly $(\mathrm{P}<0.05)$ decreased the digestion coefficients as DM and OM compared to the control group while, feeding FS at the $8 \%$ level significantly decreased the digestion coefficients of DM, OM, CF and NFE compared to the control group. Feeding FS at the 6 or $8 \%$ level in rabbits significantly decreased the daily feed intake compared to the control group. Feeding flaxseed at the three levels 4, 6 and $8 \%$ in rabbits significantly $(\mathrm{P}<0.05)$ decreased the long dorsal fat and pre-renal fat weight compared to the control group. Feeding the experimental diets contain flaxseed at different levels $(4,6$ and $8 \%)$ significantly $(\mathrm{P}<0.05)$ decreased triglycerides, total cholesterol and total alkaline phosphatase compared to those of the control group. Feeding diets contain flaxseed at the level 6 and $8 \%$ in rabbit rations significantly $(\mathrm{P}<0.05)$ increased the $\alpha-$ linolenic acid, eicosapentaenoic acid and palmitic acid levels as well as reduced the arachidonic acid. Comparing these results to the literature, it was found that inclusion of dietary flaxseed at 6 and $8 \%$ of total ration considered high levels which significantly improved the blood parameters and profile fatty acids meanwhile a slightly decreased the growth performances and digestibility. Our suggestion under these circumstances is to use the lower level of $4 \%$ in rabbit feeding, flaxseeds are used to increase the diet content in omega- 3 fatty acids, mostly alpha-linolenic acid.
\end{abstract}

Keywords: Flaxseeds, rabbits, growth performance, digestibility, carcass characteristics and blood parameters.

\section{INTRODUCTION}

Flaxseed Linumusita tissimum L. (Linaceae) is one of the most important field crops for industrial food and feed which relatively rich in protein about $25 \%$, oil about $37 \%$ and crude fibre about $10 \%$ of $\operatorname{DM}($ Singh et al., 2011). Flaxseed (FS) contains about $10 \%$ saturated fatty acids (palmitic and stearic), about $20 \%$ monounsaturated fatty acids (mainly oleic acid), more than $55 \%$ is $\alpha$-linolenic acid ( $\omega$-3 fatty acid) and about $18 \%$ linoleic acid (Prasad et al.,1999) which effectively increase the concentration of polyunsaturated fatty acids and reduce the concentration of saturated fatty acids (Benatman et al.,2011). Flaxseed is one of the best sources of n-3 fatty acids (El-Beltagi et al., 2007) and therefore used as a source of protein and energy in livestock diets as well as a good source of sulphur amino acids (methionine and cysteine) and a branched chain of amino acids (isoleucine, leucine and valine) (Oomah et al., 2007) as well as more lysine (Beaulieu et al., 2010). Flaxseed lignins are transformed into bioactive endogenous lignin' senterodiol and enterolactone as the health-promoting properties due to the impact on the hormonal activity of the organism and the antioxidative potential and cell protection against oxidative 
stress (Mitchell et al., 1998). The strong effects of antioxidative properties of lignin's, flavonoids and phenolic acids prevent the degradation of many lipids, DNA, proteins molecules being significant to the metabolism (Prasad et al., 2000) considered as a curative agent (Akhtar et al., 2013) and characterized functional properties (Martinchik et al., 2012). Several studies have demonstrated that the use of flaxseeds up to $20 \%$ in feedlot diets does not affect performance and may reduce the incidence of disease (Newkirk, 2008).

Our hypotheses to examine the pros and cons of a direct effect of feeding flaxseeds on digestibility coefficient, growth performance, meat quality, blood parameters and some fatty acids. Therefore, the present study was carried out by using growing New-Zealand White (NZW) rabbits.

\section{MATERIALS AND METHODS}

\section{Experimental design and dietary treatment:}

This work was carried out at Research and Production Station, National Research Centre (NRC) located in El-Emam Malik Village, El-Bostan, west of Nubaria and at laboratories of Animal Production Department, NRC. Sixty male NZW rabbits post-weaning with an average body weight of $698 \pm 67 \mathrm{~g}$ were used. The basal experimental diet was formulated and pelleted to cover the nutrient requirements of rabbits according to NRC (1977) as shown in Table (1). The experimental groups were classified as follows: the $1^{\text {st }}$ group fed on only basal diet $(0.0 \% \mathrm{FS})$, the $2^{\text {nd }}$ group fed the basal diet with inclusion $4 \%$ $\mathrm{FS}$, the $3^{\text {rd }}$ group fed the basal diet with inclusion $6 \% \mathrm{FS}$ and the $4^{\text {th }}$ group fed basal diet with inclusion $8 \%$ FS.

Table (1): Composition of the experimental diets (kg/100) with different levels of FS.

\begin{tabular}{|c|c|c|c|c|}
\hline \multirow{2}{*}{ Item } & \multicolumn{4}{|c|}{ Diets inclusion FS at the levels of } \\
\hline & $0 \%$ & $4 \%$ & $6 \%$ & $8 \%$ \\
\hline \multicolumn{5}{|l|}{ Ingredients: } \\
\hline$\overline{\text { Clover hay }}$ & 24 & 25 & 26 & 26.4 \\
\hline Yellow corn & 20 & 19.4 & 17 & 16 \\
\hline Barley grain & 15.9 & 12 & 10 & 9 \\
\hline Wheat bran & 22.5 & 23 & 25.4 & 26 \\
\hline Soybean meal (44\% CP) & 14.5 & 13.5 & 12.5 & 11.5 \\
\hline Flaxseeds (FS) & - & 4 & 6 & 8 \\
\hline Limestone & 1.7 & 1.7 & 1.7 & 1.7 \\
\hline Di-Ca-phosphate & 0.7 & 0.7 & 0.7 & 0.7 \\
\hline DL-methionine & 0.1 & 0.1 & 0.1 & 0.1 \\
\hline Vit. \& min. mixture* & 0.2 & 0.2 & 0.2 & 0.2 \\
\hline Sodium chloride & 0.3 & 0.3 & 0.3 & 0.3 \\
\hline Anti-fungal agent & 0.1 & 0.1 & 0.1 & 0.1 \\
\hline Total & 100 & 100 & 100 & 100 \\
\hline
\end{tabular}

Rabbits were housed in individual wire cages $(30 \times 35 \times 40 \mathrm{~cm})$ and divided into 4 equal groups divided into 3 replicates, 5 rabbits each. Stainless steel nipples for drinking and feeders allowing for each cage and feed intake was determined for each replicate.

Feed and water were offered ad libitum. Rabbits of all groups were kept under the same administrative conditions as well as average body weight and feed consumption was recorded biweekly during the experimental period.

All rabbits were used in digestibility trials over 7 days to determine the nutrient digestibility coefficients and nutritive values of the tested diets. Feed intake of experimental rations and weight of 
feces were recorded daily. Representative samples of feces were dried at $60^{\circ} \mathrm{C}$ for $48 \mathrm{hrs}$, grinded and stored for chemical analysis later.

Chemical analysis of experimental rations and feces were analysed according to AOAC (2000) methods. To determine the carcass measurements, three representative rabbits from each treatment were at a similar average weight and fasted for 12 hours before slaughtering according to Blasco et al. (1993). These were removed and individually weighed.

Full and empty weights of the digestive tract were recorded and digestive tract contents were calculated by differences between full and empty digestive tract. Weights of edible and external offal's were calculated as percentage of slaughter weight (SW). The hot carcass was weighed and divided after head separation into the front and hind parts. The $9^{\text {th }}, 10^{\text {th }}$ and $11^{\text {th }}$ ribs were frozen in polyethylene bags for later chemical analysis. The best ribs of samples were lyophilized applying the lyophilizing apparatus to prevent the triggers multiple physiological and biochemical changes in ribs meat samples in the interval (Mato et al., 2019). Samples were analysed for DM, EE and ash according to the AOAC (2000) methods, while CP percentage was determined by difference as recommended by O'Mary et al. (1979).

Blood samples were collected at the end of the experiment in heparinized tubes at slaughtering time (3 rabbits /group), and centrifuged at $3000 \mathrm{rpm}$ for 15 minutes to separate clear serum which stored at $-20^{\circ} \mathrm{C}$ for determination of some blood constituents as total lipids (TL), total cholesterol (TC), triglyceride (TG), total protein (TP), alkaline phosphatase, aspartate aminotransaminase (AST) and alanine aminotransferase (ALT) by spectrophotometer using available commercial kits. Globulin was calculated by subtracting the albumin from the total protein value (Doumas et al., 1971). The serum fatty acids were measured using gas chromatography according to the method described by Frakas et al. (1980). No feed was supplied for 18 hours before the withdrawal of blood samples.

\section{Statistical analysis:}

Collected data were subjected to statistical analysis as a one-way classification analysis of variance using the general linear model procedure of SPSS (1998). Duncan's Multiple Range Test (Duncan, 1955) was used to separate means when the dietary treatment effect was significant.

\section{RESULTS AND DISCUSSION}

\section{Chemical analysis of flaxseed and the experimental rations:}

Chemical analysis of the experimental rations is presented in Table (2). The results showed that flaxseed has high contents of CP and EE while low content of NFE. Variation in these results may show that the structure of flaxseed species can vary based on planting process, analysis, environmental factors

Table (2): Chemical analysis (\%) of flaxseeds and the experimental rations.

\begin{tabular}{|c|c|c|c|c|c|}
\hline Item & flaxseed whole & Diets & clusion & at the 1 & Is of \\
\hline Chemical composition of (DM \%) & & $0 \%$ & $4 \%$ & $6 \%$ & $8 \%$ \\
\hline$\overline{\mathrm{DM}}$ & 90.50 & 91.55 & 91.00 & 92.06 & 91.54 \\
\hline $\mathrm{OM}$ & 93.60 & 91.20 & 91.33 & 91.11 & 91.01 \\
\hline $\mathrm{CP}$ & 23.50 & 16.33 & 16.58 & 16.66 & 16.63 \\
\hline $\mathrm{CF}$ & 11.60 & 12.17 & 12.70 & 13.21 & 13.48 \\
\hline $\mathrm{EE}$ & 31.00 & 3.50 & 4.14 & 4.68 & 5.21 \\
\hline $\mathrm{NFE}$ & 27.50 & 59.20 & 57.91 & 56.56 & 55.69 \\
\hline Ash & 6.40 & 8.80 & 8.67 & 8.89 & 8.99 \\
\hline $\mathrm{GE}^{* *}(\mathrm{Kcal} / \mathrm{KgDM})$ & 5864 & 4214 & 4256 & 4277 & 4299 \\
\hline $\mathrm{DE}^{* * *}(\mathrm{Kcal} / \mathrm{KgDM})$ & 2950 & 2586 & 2587 & 2539 & 2515 \\
\hline
\end{tabular}

and diversity (Daun et al., 2003;Morris, 2008 and Maddock et al., 2005). All flaxseed treatments at the different levels used 4, 6 and $8 \%$ in rabbit rations are almost in iso-caloric and iso-nitrogenous, but the EE and NFE percentage increased as the proportion of flaxseed in the diets increases (Table 2). These 
results showed that as the level of flaxseed in ration increased, the proportion of $\mathrm{EE}$ and $\mathrm{CF}$ tend to increase while its content of nitrogen-free extract decreased.

\section{Effect of FS levels on rabbit's digestibility:}

Feeding FS at the $8 \%$ level significantly decreased the digestion coefficients as DM, OM and CF while significantly increased the digestion coefficients as EE and NFE compared to the control group (Table 3). These results may be due to the high levels of mucilage that modifies the enteric microflora activity (Martinchik et al., 2012). The significant decrease of dry matter, organic matter and crude fibre digestibility may be due to the effect of FS mucilage on the proliferation of epithelial cells which have a direct impact on the digestive and absorptive function of the small intestine (Wang et al., 2019). Decreasing the digestion coefficients at the $8 \%$ level of FS probably due to the viscous nature of the linseed and its interference with the digestion and absorption of fat (Kristensen et al., 2013).

The significant $(\mathrm{P}<0.05)$ increase of $\mathrm{EE}$ and NFE digestibility at the $8 \%$ level may be due to the polyphenols in FS (Singh et al., 2011) which can induce the alteration in the microbial composition of the intestine as a contributing this effect (Fiesel et al., 2014). In other words, the flavonoids in FS (Żuk et al., 2011) may be affecting to increase the EE digestibility in ruminants (Hassan et al., 2020). The significant $(\mathrm{P}<0.05)$ increase of $\mathrm{EE}$ and NFE digestibility at the $8 \%$ level may be due to the formula that as the fat intake in FS increased the excretion of internal fats in the stool decreased in less effect on the calculated apparent digestibility (Van Manen et al., 1989). With increasing the dietary linseed percentage the digestibility of EE increased (Peiretti et al., 2007). This discrepancy between different studies may be not only due to the utilized lipid sources and the level of rabbit's digestibility, but could also be attributed to animal species (Huo et al., 2019). In other words, increased EE and NFE digestibility with higher supplemented fat diets $8 \%$ FS in this study may be a result of the reduced DM intake observed with the added more FS diets as showed in ruminant by Haddad and Younis (2003). A similar result is consistent with El Hag et al. (1985), who observed an increase in EE digestion when 10\% tallow was added to sheep diets.

Table (3): Digestibility coefficient of nutrients in growing rabbits fed different levels of flaxseed.

\begin{tabular}{|c|c|c|c|c|c|c|}
\hline \multirow[b]{2}{*}{ Item } & \multicolumn{6}{|c|}{ Diets inclusion FS at the levels of } \\
\hline & $0 \%$ & $4 \%$ & $6 \%$ & $8 \%$ & $\pm \mathrm{SE}$ & Sig \\
\hline Dry matter intake, $\mathrm{g} / \mathrm{h} / \mathrm{d}$ & $95.97^{\mathrm{a}}$ & $91.61^{\mathrm{a}}$ & $82.76^{b}$ & $61.39^{b}$ & 1.86 & \\
\hline Nutrients digestibility,\%: & & & & & & \\
\hline DM & $78.38^{\mathrm{a}}$ & $73.18^{\mathrm{ab}}$ & $61.72^{\mathrm{b}}$ & $61.39^{b}$ & 3.07 & * \\
\hline OM & $80.27^{\mathrm{a}}$ & $74.75^{\mathrm{ab}}$ & $64.35^{\mathrm{b}}$ & $63.81^{\mathrm{b}}$ & 3.27 & * \\
\hline $\mathrm{CP}$ & 78.89 & 78.84 & 69.24 & 66.21 & 3.66 & NS \\
\hline $\mathrm{CF}$ & $49.30^{\mathrm{a}}$ & $41.04^{\mathrm{ab}}$ & $40.45^{\mathrm{ab}}$ & $32.12^{\mathrm{b}}$ & 2.72 & \\
\hline $\mathrm{EE}$ & $72.43^{\mathrm{b}}$ & $75.00^{\mathrm{ab}}$ & $82.51^{\mathrm{ab}}$ & $85.95^{\mathrm{a}}$ & 2.74 & * \\
\hline NFE & $69.56^{\mathrm{b}}$ & $79.70^{\mathrm{a}}$ & $81.06^{\mathrm{a}}$ & $83.89^{\mathrm{a}}$ & 2.09 & * \\
\hline Feeding value, $\%$ : & & & & & & \\
\hline TDN & $74.41^{\mathrm{a}}$ & $72.72^{\mathrm{a}}$ & $67.98^{\mathrm{ab}}$ & $63.96^{\mathrm{b}}$ & 2.00 & * \\
\hline DCP & 13.00 & 12.94 & 11.44 & 11.10 & 0.64 & NS \\
\hline
\end{tabular}

\section{Effect of FS levels on the rabbit's growth performance:}

Feeding FS at the 6 or $8 \%$ level in rabbit rations significantly $(\mathrm{P}<0.05)$ decreased the daily feed intake compared to the control group (Table 4). This result may be due to the FS gel may be slowing down the emptying of the stomach and slightly effect on appetite (Kristensen et al., 2011). The gradual decrease of the daily feed intake at the three levels used of FS probably due to the secoisolariciresinol diglucoside (SDG) which enhances the production of leptin enzyme that reduces the feed intake (Orzechowski et al., 2002). As well as the protease inhibitors (e.g., trypsin inhibitors) as anti-nutritional compounds in FS may decrease the protein absorption and consequently diminish the growth performance (Cardoso et al., 2012). A similar result showed that supplementation of different types of fats did not influence animal performance in Dorper sheep (Behan et al., 2019). 
Feeding FS at the 6 or $8 \%$ level in rabbit rations decreased the daily weight gain compared to the control group (Table 4). The reduction in growth performance may be due to the phytic acid effect in FS that binds proteins and minerals decreasing the bioavailability (Robert et al., 2017). On the other hand, the flaxseed lignin may have a direct relation to health improvement via both pangs of hunger suppressed (Martinchik et al., 2012). Also, probably due to the FS mucilage that absorbs water that increases the intestinal viscosity causing a laxative effect result in reduced performance (Alzueta et al., 2003). Some authors have linked the presence of toxins in whole flaxseeds with reduced energy use and thus poor growth rates (Bianchi et al., 2006). Similar studies showed that rabbits fed diets containing whole flaxseed and fully extruded flaxseed had a low growth rate (Colin et al., 2005 and Bianchi et al., 2006).

The reduction in growth performance probably due to the mucilage percentage that modifies the enteric microflora activity producing several unfavourable changes in the gastrointestinal tract which slows down the emptying of the stomach, slightly affected appetite, palatability and feed intake (Martinchik et al., 2012). In other words, these results may be due to the flaxseed characterize within fibre crops by a genotype for heavy metal tolerance or accumulation (Saleem et al., 2020). Also, the reduction in growth performance probably due to the B6 deficiency in FS as observed in broilers by Newkirk (2008). The performance reduction may be due to the FS constipation effect as shown in sows (Lawrence et al., 2004).

Table (4): Growth performance as affected by different levels of FS in ration of rabbits.

\begin{tabular}{lcllllll}
\hline & \multicolumn{7}{l}{ Diets inclusion FS at the levels of } \\
\cline { 3 - 8 } Item & $0 \%$ & $4 \%$ & $6 \%$ & $8 \%$ & \pm SE & Sig \\
\hline Initial weight & $(\mathrm{kg})$ & 0.696 & 0.699 & 0.688 & 0.706 & 0.18 & $\mathrm{NS}$ \\
Final weight & $(\mathrm{kg})$ & 2.140 & 2.110 & 1.998 & 1.866 & 0.81 & $\mathrm{NS}$ \\
Final gain weight & $(\mathrm{kg})$ & 1.444 & 1.411 & 1.310 & 1.160 & 0.73 & $\mathrm{NS}$ \\
Daily weight gain & $(\mathrm{g})$ & 25.8 & 25.2 & 23.4 & 20.7 & 3.05 & $\mathrm{NS}$ \\
Feed intake & $(\mathrm{kg})$ & $4.66^{\mathrm{a}}$ & $4.55^{\mathrm{a}}$ & $4.24^{\mathrm{b}}$ & $4.20^{\mathrm{b}}$ & 0.89 & $*$ \\
Daily feed intake & $(\mathrm{g})$ & $83.2^{\mathrm{a}}$ & $81.3^{\mathrm{a}}$ & $75.7^{\mathrm{b}}$ & $75.0^{\mathrm{b}}$ & 5.82 & $*$ \\
Feed conversion ratio g DMI/g gain & 3.23 & 3.23 & 3.24 & 3.62 & 2.66 & $\mathrm{NS}$ \\
\hline
\end{tabular}

a and b: means in the same row within each treatment having different superscripts differ significantly at P<0.05. SE: standard error of the mean. NS: non-significant. $\quad *: P<0.05$.

\section{Effect of FS levels on the rabbit's carcass characteristics:}

Feeding flaxseed at the three levels $(4,6$ and $8 \%)$ in rabbit rations significantly $(\mathrm{P}<0.05)$ decreased the long dorsal fat and pre-renal fat weight compared to the control group (Table 5). These results may be due to the high proportion of lignin fibres "secoisolariciresinol diglycoside" which are responsible for the reduction of visceral fat mass (Fukumitsu et al., 2008 and Park and Velasquez, 2012). On the contrary, some results showed that the fat thickness of the FS groups was greater $(\mathrm{P}<0.05)$ than the other groups

Table (5): Carcass characteristics as affected by different levels of FS in ration of rabbits.

\begin{tabular}{|c|c|c|c|c|c|c|}
\hline \multirow[b]{2}{*}{ Item } & \multicolumn{6}{|c|}{ Diets inclusion FS at the levels of } \\
\hline & $0 \%$ & $4 \%$ & $6 \%$ & $8 \%$ & $\pm \mathrm{SE}$ & Sig \\
\hline Live body weight (g) & 2032 & 2031 & 2034 & 2036 & 19.5 & NS \\
\hline Slaughter wt & 1228 & 1256 & 1261 & 1290 & 70.50 & NS \\
\hline Digestive tract wt (g) & 234 & 227 & 225 & 222 & 5.70 & NS \\
\hline Long dorsal fat wt (g) & $55.3^{\mathrm{a}}$ & $50.3^{\mathrm{b}}$ & $49.3^{\mathrm{b}}$ & $45.3^{\mathrm{c}}$ & 3.85 & $*$ \\
\hline Prerenal fat wt $\quad(\mathrm{g})$ & $21.7^{\mathrm{a}}$ & $19.0^{\mathrm{b}}$ & $16.0^{\mathrm{c}}$ & $13.7^{\mathrm{d}}$ & 2.85 & $*$ \\
\hline Head & 165.0 & 165.7 & 165.7 & 164.3 & 2.01 & NS \\
\hline Heart & $7.3^{\mathrm{c}}$ & $8.4^{\mathrm{b}}$ & $8.9^{\mathrm{b}}$ & $9.8^{\mathrm{a}}$ & 0.70 & $*$ \\
\hline Liver & $74.7^{\mathrm{b}}$ & $76.7^{\mathrm{b}}$ & $79.0^{\mathrm{ab}}$ & $82.3^{\mathrm{a}}$ & 3.92 & $*$ \\
\hline
\end{tabular}

(Whetsell et al., 2003). Feeding flaxseed at the three levels used (4, 6 and $8 \%$ ) in rabbit rations significantly $(\mathrm{P}<0.05)$ increased the heart weight (Table 5). This result probably due to the biologically 
active substances in FS, such as lignin, fibres and linoleic acid which provide the cardioprotective effects (Prim et al., 2012). Feeding FS at the three levels used in rabbit rations slightly increases the liver weight (Table 5). This result probably due to that the oil in FS which can increase the concentrations of the $n-3$ fatty acid ALA in liver tissue (Barceló and Murphy, 2009). In other words, the essential amino acids in FS are of great importance in the synthesis of protein which contributes to the repair and maintenance of cells, tissues and organs (Omoni and Aluko, 2006).

\section{Chemical analysis of the $9^{\text {th }}, 10^{\text {th }}$ and $11^{\text {th }}$ ribs fed the experimental ration:}

Feeding FS at 6 or $8 \%$ level significantly $(\mathrm{P}<0.05)$ increased the chemical analysis on DM basis of CP while significantly $(\mathrm{P}<0.05)$ decreased the $\mathrm{EE}$ in the meat ribs compared to the control group (Table 6). These results probably due to the changes in the lipid composition of the diet being able to alter the protein content of meat (Bourre, 2004). We can conclude that FS in rabbit diets improved the nutrition value of rabbit meat. On the contrary, flaxseed at $5 \%$ or $7.5 \%$, did not affect the total lipid content in thigh tissues (Roth-Maier et al., 1998). In general, feeding flaxseed tends to increase meat quality parameters such as the marbling score (Maddock et al., 2005 and 2006).

Table (6): Chemical analysis of $9^{\text {th }}, 10^{\text {th }}$ and $11^{\text {th }}$ ribs as affected by different levels of FS in ration of rabbits.

\begin{tabular}{lcccccc}
\hline & \multicolumn{5}{c}{ Diets inclusion FS at the levels of } \\
\cline { 2 - 7 } Item & $0 \%$ & $4 \%$ & $6 \%$ & $8 \%$ & \pm SE & Sig \\
\hline Chemical analysis on DM basis: & & & & & & \\
CP & $57.17^{\mathrm{b}}$ & $60.07^{\mathrm{b}}$ & $64.60^{\mathrm{a}}$ & $64.97^{\mathrm{a}}$ & 2.05 & $*$ \\
EE & $35.37^{\mathrm{a}}$ & $32.46^{\mathrm{a}}$ & $25.27^{\mathrm{b}}$ & $25.06^{\mathrm{b}}$ & 1.93 & $*$ \\
Ash & $7.46^{\mathrm{b}}$ & $7.47^{\mathrm{b}}$ & $10.13^{\mathrm{a}}$ & $9.97^{\mathrm{a}}$ & 0.28 & $*$ \\
\hline
\end{tabular}

$a$ and b: means in the same row within each treatment having different superscripts differ significantly at P<0.05. SE: standard error of the mean. NS: non-significant $*: P<0.05$.

\section{Effect of FS levels on the rabbit's blood parameters:}

Feeding flaxseed at different levels $(4,6$ and $8 \%)$ in rabbits significantly $(\mathrm{P}<0.05)$ decreased triglycerides, total cholesterol and total alkaline phosphatase compared to the control group (Table7). The decreased value of triglycerides probably due to the high soluble mucilage fibre lignin content of FS (about 28\% by weight) may have yielded the reduction attenuated cholesterol values (Pan et al., 2009).

Table (7): Blood serum constituents as affected by different levels of FS in ration of rabbits.

\begin{tabular}{lcccccc}
\hline & \multicolumn{7}{c}{ Diets inclusion FS at the levels of } \\
\cline { 2 - 7 } Item & $0 \%$ & $4 \%$ & $6 \%$ & $8 \%$ & \pm SE & Sig \\
\hline Albumin (g/dl) & 3.37 & 3.22 & 3.01 & 3.48 & 0.42 & NS \\
Globulin (g/dl) & 2.26 & 2.10 & 2.79 & 2.62 & 0.43 & NS \\
Total protein (g/dl) & 5.63 & 5.32 & 5.80 & 6.10 & 0.35 & $\mathrm{NS}$ \\
Triglycerides (mmol/l) & $2.36^{\mathrm{a}}$ & $1.47^{\mathrm{b}}$ & $1.39^{\mathrm{b}}$ & $1.35^{\mathrm{b}}$ & 0.56 & $*$ \\
Total cholesterol (mmol/l) & $16.8^{\mathrm{a}}$ & $14.5^{\mathrm{a}}$ & $12.6^{\mathrm{b}}$ & $11.4^{\mathrm{b}}$ & 1.87 & $*$ \\
Alkaline phosphatase (U/I) & $66.6^{\mathrm{a}}$ & $52.7^{\mathrm{b}}$ & $53.8^{\mathrm{b}}$ & $55.4^{\mathrm{b}}$ & 2.33 & $*$ \\
AST (U/l) & $94.7^{\mathrm{a}}$ & $86.4^{\mathrm{a}}$ & $69.6^{\mathrm{b}}$ & $65.2^{\mathrm{b}}$ & 3.51 & $*$ \\
ALT (U/l) & 33.7 & 33.6 & 32.9 & 32.7 & 1.35 & $\mathrm{NS}$ \\
\hline
\end{tabular}

$a$ and $b:$ means in the same row within each treatment having different superscripts differ significantly atP $<0.05$. SE: standard error of the mean. NS: non-significant. *: $P<0.05$.

While, the reduction of cholesterol concentrations may be attributed to the essential omega-3 fatty acid (Dupasquier et al., 2007). Similar results showed a significant reduction in triglycerides, total cholesterol 
and low-density lipoprotein-cholesterol (LDL-C) levels were observed (Saxena and Katare, 2014) when feeding on FS. It is more likely that soluble mucilage fibre resulting from flaxseed lignin extracts (Fukumitsu et al., 2008) may have yielded the attenuated cholesterol values observed in our study. Feeding flaxseed at different levels $(6$ and $8 \%)$ in rabbits significantly $(\mathrm{P}<0.05)$ decreased the serum AST and total alkaline phosphatase compared to the $0 \%$ flaxseed group (Table 7). These results may be due to the ability of flaxseed oil to attenuate liver injury by reducing ALT and AST levels (Chen et al., 2015) as well as altered gut microbiota and the decrease of liver inflammation (Zhang et al., 2017) as well as may due to the lack of inflammation (Chen et al., 2015).

\section{Effect of FS levels on the rabbit's serum fatty acid:}

Feeding on flaxseed at the 6 and $8 \%$ levels in rabbit rations significantly $(\mathrm{P}<0.05)$ increased the $\alpha$ linolenic acid (ALA), eicosapentaenoic acid and palmitic acid levels (Table 8). These results showed that FS enriched diets with free fatty acids expression in the rabbit serum blood. This result probably due to the long period (56 days) of an experiment is more efficient at increasing ALA content in rabbit meat. A similar result showed that feeding higher levels of flaxseeds for shorter periods versus lower levels for longer periods is more efficient at increasing ALA content in pig meat (Juarez et al., 2010). Feeding ground flaxseeds slightly modifies the long-chain fatty acid profile in the rib eye, by increasing both linoleic (C18:2) and alpha-linolenic (C18:3) acids (LaBrune et al., 2008), as well as the unsaturated fatty acids in the muscle (Maddock et al., 2005). A similar result showed that both raw and processed flaxseed increased fatty acids (saturated or unsaturated) content but decreased or had no effect on short to mediumchain fatty acids and on longer chain fatty acids in milk (Glasser et al., 2008). Feeding on flaxseed at the 6 and $8 \%$ levels in rabbit rations significantly $(\mathrm{P}<0.05)$ reduced the arachidonic acid (Table 8). Similar results in blood and tissues are reported by Gotoh et al. (2007). Our results showed that feeding FS in rabbit ration improved the nutritional value of rabbit meat as showed by Kouba et al. (2008). This study confirmed that dietary FS could be considered as a way of enriching the n-3 PUFA in a rabbit. Similar results showed that most of the saturated fatty acids decreased with increasing flaxseed levels except C18:0 while unsaturated fatty acids increased (Hurtaud et al., 2010).

Table (8): Serum fatty acids profiles as affected by different levels of FS in ration of rabbits.

\begin{tabular}{lccccccc}
\hline & & \multicolumn{5}{c}{ Diets inclusion FS at the levels of } \\
\cline { 3 - 8 } Item & Lipid numbers & $0 \%$ & $4 \%$ & $6 \%$ & $8 \%$ & \pm SE & Sig \\
\hline Arachidonic acid & $\mathrm{C} 20: 4 \mathrm{n}-6$ & $3.14^{\mathrm{a}}$ & $3.03^{\mathrm{a}}$ & $2.72^{\mathrm{b}}$ & $2.08^{\mathrm{c}}$ & 0.15 & $*$ \\
Eicosapentaenoic acid & $\mathrm{C} 20: 5 \mathrm{n}-3$ & $0.18^{\mathrm{c}}$ & $0.62^{\mathrm{b}}$ & $0.78^{\mathrm{a}}$ & $0.84^{\mathrm{a}}$ & 0.10 & $*$ \\
Palmitic acid & $\mathrm{C} 16: 1 \mathrm{n}-7$ & $0.44^{\mathrm{d}}$ & $0.56^{\mathrm{c}}$ & $0.74^{\mathrm{a}}$ & $0.66^{\mathrm{b}}$ & 0.13 & $*$ \\
Stearic acid & $\mathrm{C} 18: 1 \mathrm{n}-9$ & 42.51 & 43.8 & 42.6 & 42.5 & 4.50 & $\mathrm{NS}$ \\
Linoleic acid & $\mathrm{C} 18: 2 \mathrm{n}-6$ & 9.99 & 10.26 & 9.95 & 9.95 & 0.64 & $\mathrm{NS}$ \\
Alpha- linolenic acid & $\mathrm{C} 18: 3 \mathrm{n}-3$ & $0.92^{\mathrm{d}}$ & $2.86^{\mathrm{c}}$ & $3.91^{\mathrm{b}}$ & $4.87^{\mathrm{a}}$ & 0.15 & $*$ \\
\hline a,b, cand d: means in the same row within each treatment having different superscripts differ significantly at $P<0.05$.
\end{tabular}

SE: standard error of the mean. NS: non-significant. *: $P<0.05$.

\section{CONCLUSION}

Feeding flaxseeds at 6 and $8 \%$ of the total rabbit ration was considered to be of high levels, leading to a decrease in growth performance and digestion coefficient, while slightly improving the fatty acid profile. Our suggestion under these circumstances is to use the lower level of $4 \%$ in rabbit feeding, flaxseeds are used to increase the diet content in omega-3 fatty acids, mostly alpha-linolenic acid.

\section{REFERENCES}

Akhtar, S.;T. Ismail and M. Riaz (2013). Review Flaxseed-A miraculous defence against some critical maladies. Pak. J. Pharm. Sci., 1:199-208. 
Alzueta, C.; M. L. Rodriguez; M. T. Cutuli; A. Rbolem; L. T. Ortiz; C. Centeno and J.Trevino (2003).Effect of whole and demucilaged linseed in broiler chicken diets on digesta viscosity, nutrient utilization and intestinal microflora. Br. Poult. Sci., 44 (1): 67-74.

AOAC (2000).Association of Official Analytical Chemists, Official Methods of Analysis, $17^{\text {th }}$ ed., Washington, DC, USA.

Barceló-Coblijn, G. and E. J. Murphy (2009). Alpha-linolenic acid and its conversion to longer chain n-3 fatty acids: Benefits for human health and a role in maintaining tissue n-3 fatty acid levels. Prog. Lipid Res., 48:355-374.

Beaulieu, A. D.; J. F. Patience; R. T. Zijlstra; J. L. Aalhus and M. E. R. Dugan (2010). Impact of feeding diets containing extruded flaxseed meal \& vitamin $\mathrm{E}$ in finishing swine. Banff Pork Seminar Proceedings: A30.

Behan, A. A.; T. C. Loh; S. Fakurazi;U.Kaka; A. Kaka and A. A.Samsudin (2019). Effects of supplementation of Rumen Protected Fats on Rumen Ecology and Digestibility of Nutrients in Sheep. Animals (Basel), 7: 400.

Benatman, F.; M. Kouba; A. Youyou and J. Mourot (2011).Effect of a linseed diet on lipogenesis, fatty acid composition and stearoyl-CoA-desaturase in rabbits.Animal, 5:12:1993-2000.

Bianchi, M.;M. Petracci and C. Cavani (2006). Effects of dietary inclusion of dehydrated lucerne and whole linseed on rabbit meat quality. World Rabbit Sci., 14: 247-258.

Blasco, A.; J. Quhayaun and G. Masoscro (1993).Hormonization of criteria and terminology in rabbit meat research. World Rabbits Sciences, 1: 3-10.

Blaxter, K.L. (1968). The energy metabolism of ruminants.2nd ed. Charles Thomas Publisher. Spring field. Illinois, USA.

Bourre, J. (2004).Effect of increasing the omega-3 fatty acid in the diets of animals on the animal products consumed by humans. Med. Sci., 21: 773-779.

Cardoso Carraro J.C.; M.I.D.S. Dantas; A. C. R. Espeschit; H.S.D . Martino and S.M.R. Ribeiro (2012).Flaxseed and human health: Reviewing benefits and adverse effects. Food Rev. Int., 28:203230.

Chen, W.; Y. Y. Jiang; J. P.Wang; B. X.Yan; Y. Q. Huangand and Z. X. Wang (2015). Effect of flaxseed on the fatty acid profile of egg yolk and antioxidant status of their neonatal offspring in Huoyangeese. Animal, 9(11): 1749-1755.

Colin, M.; N. Raguenes; G. Le Berre; S. Charrier; A.Y. Prigent and G. Perrin (2005).Influence d'un enrichissement de l'alimentenacidesgrasoméga 3 provenant de graines de linextrudées (Tradi-Linß) sur les lipideset les caractéristiques de la viande de lapin. J. Rec. Cunicole, Paris, France, 163-166.

Daun, J.K.; V.J. Barthet; T.L. Chornick and S. Duguid (2003).Structure, composition, and variety development of flaxseed.In Thompson, L. U. and Cunnane, S. C. (Eds). Flaxseed in Human Nutrition, 2nd ed, p. 1-40. Champaign, Illinois: AOCS Press.

Doumas, B.;W.W. Wabson and H. Biggs (1971). Albumin standards and measurement of serum with bromocrisol green. Clin. Chem. Acta, 31: 87.

Duncan, D.B. (1955). Multiple range and multiple F-test biometrics 11: 1- 42.

Dupasquier, C.M.;E. Dibrov; A.L. Kneesh; P.K. Cheung; K.G. Lee and H.K. Alexander (2007). Dietary flaxseed inhibits atherosclerosis in the LDL receptor-deficient mouse in part through antiproliferative and anti-inflammatory actions. J. Physiol Heart Circ Physiol., 293: 2394-2402.

El-Beltagi, H.S; Z.A. Salama and D.M. El-Hariri (2007).Evaluation of fatty acids profile and the content of some secondary metabolites in seeds of different flax cultivars (Linum usitatissimum L.). General Appl. Plant Phys., 33: 187-202.

El-Hag, M.G.;O.I. Kurdi and S.O. Mahgoub (1985). Performance and carcass characteristics of Sudan desert sheep and goats on high roughage diets with added fat. Anim. Feed Sci. Technol., 13:147-153.

Fekete, S. and T. Gippert (1986).Digestibility and nutritive value of nineteen important feedstuffs for rabbits. J. Appl. Rabbit Res., 9 (3): 103- 108. 
Fiesel, A.; D. K. Gessner; E.Most and K. Eder (2014).Effects of dietary polyphenol-rich plant products from grape or hop on pro-inflammatory gene expression in the intestine, nutrient digestibility and faecal microbiota of weaned pigs. BMC Vet Res., 10: 196.

Frakas, T.; L. I. Csengeri; F. Majoros and J. Olah (1980). Metabolism of fatty acid in fish III combined effect of environmental temperature and diet on formation and deposition of fatty acids in the carp. Aquaculture, 20:29-40.

Fukumitsu, S.; K. Aida and N. Ueno (2008). Flaxseed lignan attenuates high-fat diet-induced fat accumulation and induces adiponectin expression in mice. Br. J Nutr., 100: 669-676.

Glasser, F.; A. Ferlay and Y. Chilliard (2008). Oilseed lipid supplements and fatty acid composition of cow milk: a meta-analysis. J. Dairy Sci., 91: 4687-4703.

Gotoh, C.; Y.H. Hong; T. Iga; D. Hishikawa; Y. Suzuki; S.H. Song; K.C. Choi; T. Adachi; A. Hirasawa; G. Tsujimoto ; S. Sasaki and S.G. Roh (2007).The regulation of adipogenesis through GPR120.Bioch. Biophys. Res. Commun., 9:591-597.

Haddad, S.G. and H.M. Younis (2003). The effect of adding ruminally protected fat in fattening diets on nutrient intake, digestibility and growth performance of Awassi lambs. Anim. Feed Sci. Technol., 113:61-69.

Hassan, F.; M. A. Arshad; M.Li; M.S. Rehman and J. Huang (2020).Potential of Mulberry Leaf Biomass and Its Flavonoids to Improve Production and Health in Ruminants: Mechanistic Insights and Prospects. Animals (Basel) Nov, 10(11): 2076.

Huo, W.; M. Li; J. Wang; Z. Wang; Y. Huang and W. Chen (2019). On growth performance, nutrient digestibility, blood $\mathrm{T}$ lymphocyte subsets, and cardiac antioxidant status of broilers. Anim. Nutr., 5: 68-73.

Hurtaud, C.; F. Faucon; S. Couvreur and J. L. Peyrault (2010). Linear relationship between increasing amounts of extruded linseed in dairy cow diet and milk fatty acid composition and butter properties. J. Dairy Sci., 93:1429-1443.

Juarez, M.; M. E. R. Dugan ; N . Aldai; J. L. Aalhus; J. F. Patience; R. T. Zijlstra and A. D. Beaulieu (2010).Feeding co-extruded flaxseed to pigs: effects of duration and feeding level on growth performance and backfat fatty acid composition of grower-finisher pigs. Meat Sci., 84: 578-584.

Kouba, M.; F. Benatmane; J.E. Blochet and J. Mourot (2008).Effect of a linseed diet on lipid oxidation, fatty acid composition of muscle, perirenal fat, and raw and cooked rabbit meat. Meat. Sci., 80: 829834.

Kristensen, M.; K. E. B. Knudsen; H. Jørgensen; D.Oomah; S. Bügel; S. Toubro; I.Tetens and A. Astrup (2013). Linseed Dietary Fibers Reduce Apparent Digestibility of Energy and Fat and Weight Gain in Growing Rats. Nutrients, 5(8): 3287-3298.

Kristensen, M.; M. G. Jensen; J. Aarestrup; K. E. Petersen; L. Søndergaard and M.S. Mikkelsen (2011). Flaxseed dietary fibers lower cholesterol and increase fecal fat excretion, but magnitude of effect depend on food type. Nutr. Metab. (Lond., 9: 8).

La Brune, H. J.; C. D. Reinhardt; M. E. Dikeman and J. S. Drouillard (2008). Effects of grain processing and dietary lipid source on performance, carcass characteristics, plasma fatty acids, and sensory properties of steaks from finishing cattle. J. Anim. Sci., 86:167-172.

Lawrence, B. V.; D. J. Overend and S.A. Hansen (2004).Sow productivity responses, from long term continuous inclusion of flaxmeal in commercial environment. Final report submitted to Flax Council of Canada.

Maddock, T. D. ; M. L. Bauer; K. B. Koch; V. L. Anderson; R. J. Maddock; G. Barceló-Coblijn; E. J. Murphy and G. P. Lardy (2006). Effect of processing flaxseed in beef feedlot diets on performance, carcass characteristics and trained sensory panel ratings. J. Anim. Sci., 84:1544-1551.

Maddock, T.D.; V.L. Anderson and G.P. Lardy (2005).Using flax in livestock diets.NDSU extension service, North Dakota Agricultural Experiment Station, North Dakota State University, Fargo, ND 58105.

Martinchik ,A.N.; A.K. Baturin; V.V. Zubtsov and V.Molofeev(2012).Nutritional value and functional properties of flaxseed. Vopr Pitan., 3:4-10. 


\section{Ibrahim et al.}

Mato, A.; R. R..Vázquez; M.L. Pedrouso; S. Bravo; D. Franco and C. Zapata (2019). The first evidence of global meat phosphoproteome changes in response to pre-slaughter stress. BMC Genomics. 20: 590 .

Mitchell ,J.H.; P.T. Gardner; D.B. McPhail; P.C. Morrice; A.R. Collins and G.G. Duthie (1998). Antioxidant efficacy of phytoestrogens in chemical and biological model systems. Arch. Biochem. Biophys, 360:142-148.

Morris, D.H. (2008). Linseed in the ruminant diet, adding linseed to feed enhances the fat profile of milk. Flax Council of Canada, 465-167 Lombard Ave., Winnipeg, MB, Canada R3B 0T6.

Newkirk, R. (2008). Flax feed industry guide. Flax Canada 2015, Winnipeg, Manitoba. 24p.

NRC (1977).National Research Council. Nutrient Requirements of Rabbits, National Academy of Science, Washington, DC, USA.

O'Mary, C.C.; L.M. Everett and A.D. Graig(1979).Production and carcass characteristics of Angus and Charolais x Angus steers. J. Anim. Sci., 48: 239.

Omoni, A.O. and R.E. Aluko (2006).Mechanism of the inhibition of calmodulin-dependent neuronal nitric oxide synthase by flaxseedproteinhydrolysates.J. of Amer. Oil Chemis. Soc., 83: 335-340.

Oomah, B.D.; B. Berekoff; C. Li-Chan; G. Mazza; E.Kenaschuk and S. Duguid (2007). Cadmiumbinding protein components of flaxseed: Influence of cultivar and location. Food Chem., 100: 318325.

Orzechowski, A.; P. Ostaszewski; M. Jank and S.J. Berwid (2002). Bioactive substances of plant origin in food-impact on genomics Reprod. Nutr. Dev., 42:461-477.

Pan, D. Y.; D.W. Wendy; H.F. Oscar and Xu.Lin (2009).Meta-analysis of the effects of flaxseed interventions on blood lipids. Am. J. Clin. Nutr., 90:288-297.

Park, J.B. and M.T. Velasquez (2012).Potential effects of lignan-enriched flaxseed powder on bodyweight, visceral fat, lipid profile and blood pressure in rats. Fitoterapia, 83: 941-6.

Peiretti, P.G.;P.P. Mussa; L. Prola and G. Meineri (2007).Use of different levels of false flax (Camelina sativa L.) seed in diets for fattening rabbits. Live. Sci., 107: 192-198.

Prasad, K.; S.V.Mantha; A.D.Muir and N.D. Westcott (1999).Reduction of hypercholesterolemic atherosclerosis by CDC-flaxseed with very low alpha-linolenic acid. Atherosclerosis, 136: 367-375.

Prasad, K.; S.V. Mantha; A.D. Muir and N.D. Westcott (2000).Protective effect of secoisolariciresinoldiglucoside against streptozotocin-induced diabetes and its mechanism. Mol. Cell. Biochem., 206:141-150.

Prim, C.R.; L.A. Baroncini; L.B. Precoma; P.H. Caron; G.Winter; M.O.Poletti and D.B. Precoma (2012). Effects of linseed consumption for a short period of time on lipid profile and atherosclerotic lesions in rabbits fed a hypercholesterolaemic diet. Br. J. Nutr., 107(5):660-664.

Robert, D.; S. Bożena; B.Łukasz; P. Aleksander; S.J.Anna and Ż. Krzysztof (2017).Solid-state fermentation reduces phytic acid level, improves the profile of myo-inositol phosphates and enhances the viability of selected minerals in flaxseed oil cake. Food Techn. Biotec., 55(3): 413-419.

Roth-Maier, D.A; K. Eder and M. Kirchgessner (1998). Live performance and fatty acid composition of meat in broiler chickens fed diets with various amount of ground or whole flaxseed. J Anim. Physiol. Anim. Nutr, 79:260-268.

Saleem, M. H.; S. Ali; S. Hussain; M. Kamran; M. S. Chattha; S. Ahmad; M. Aqeel; M. Rizwan;N. H. Aljarba;S.Alkahtani and M. M. Abdel-Daim (2020). Flax (Linumusita tissimum L.): A Potential Candidate for Phytoremediation? Biological and Economical Points of View. Plants, 9:496.

Saxena, S. and C. Katare (2014). Evaluation of flaxseed formulation as a potential therapeutic agent in mitigation of dyslipidemia. Biomed. J., 6:386-390.

Singh, K.K.; D.Mridula; J. Rehal and P.Barnwal (2011). Flaxseed: A Potential Source of Food, Feed and Fiber. Critical Reviews in Food Science and Nutrition, 51:210-222.

SPSS (1998).Statistical Package for Social Sciences, Chicago, USA. 
Van Manen, D.G.; M.W.A. Verstegen; M.W.A. Meijer and A.C. Beynen (1989).Growth performance by rabbits after isoenergetics substitution of dietary fat for carbohydrates.Nutr. Rep. Int., 40: 443-450.

Wang, L.;S.Yan; J. Li; Y. Li; X. Ding; J. Yin; X. Xiong; Y. Yin and H. Yang. (2019). Rapid Communication: The relationship of enterocyte proliferation with intestinal morphology and nutrient digestibility in weaning piglets. J. Anim. Sci., 97(1): 353-358.

Whetsell, M. S.; E. B. Rayburn and J. D. Lozier (2003). Human health effects of fatty acids in beef. Fact Sheet: West Virginia University \& USDA Agriculture.

Zhang, J.J.; X. Meng; Y.Li; Y. Zhou; D.P. Xu; S. Li and H.B. Li (2017). Effects of melatonin on liver injuries and diseases.Int. J. Mol. Sci., 18, 673.

Żuk, M.; A. Kulma; L. Dymińska; K. Szołtysek; A. Prescha; J. Hanuzaand and J. Szopa (2011). Flavonoid engineering of flax potentiate its biotechnological application. BMC Biotechnol., 11: 10.

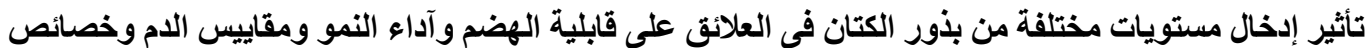

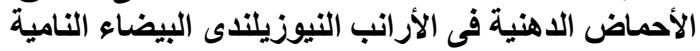

شوقى احمد محمد إبراهيم'، ياسر احمد عبد الفتاح النميرى1 ، فاطمة منصور محمد سالمان ${ }^{1}$ و بكرى احمد بكرى2 1قسم الانتاج الحيو/نى- شعبة البحوث الزراعية والبيولوجية ـ المركز القومى للبحوث- مصر.$$
\text { 2قفم بحوث المحاصيل الحقلية - شعبة البحوث الزراعية والبيولوجية- المركز القومي للبحوث- مصر. }
$$

يهدف هذا البحث الى دراسة تأثير إدخال مستويات مختلفة من بذور الكتان في علائق الار انب النامية وتأثثير إدراج هذه المستويات علي

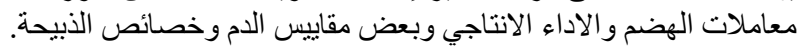

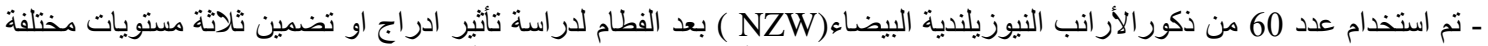

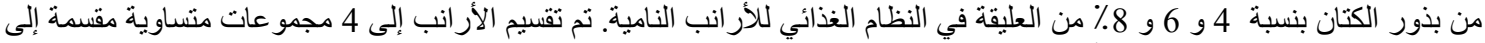
3 مكرر ات كل منها تحتوى على 5 أر انب وقسمت المجمو عات عشو ائيا في تجربة نمو استمرت لمدة 8 اسابيع وكانت العلائق كالاتي: ـ المجمو عة الاولي: غذيت علي العليقة الأساسية. ـ المجمو عة الثانية: غذيت علي العليقة الاساسية مع إدر اج بذور الكتان في العليقة بمستوي 4\%. ـ المجمو عة الثالثة: غذيت علي العليقة الاساسية مع إدر اج بذور الكتان في العليقة بنسبة 6\%. ـ المجموعة الرابعة: غذيت علي العليقة الاساسية مع إدراج بذور الكتان في العليقة بنسبة 8\%. وكانت النتائج كما يلى:

* ادي إدخال بذور الكتان في العليقة بمستوي 6\% الإلي انخفاض في معاملات هضم المادة الجافة والمادة العضوية مقارنة بالمجموعة الاولي المغذاه علي العليقة الاساسية.

* ادي إخخال بذور الكتان في العليقة بنسبة 8\% الي انخفاض في معاملات هضم الالياف والمستخلص الخالي من الازوت مقارنة بالمجمو عة المغذاه علي العليقة الضابطة.

* ادت التغذية بإدخال بذور الكتان بنسبة 6 و8\% الي انخفاض كبير في كمية المأكول اليومي ومتوسط النمو اليومى مقارنة بالمجموعة الضابطة.

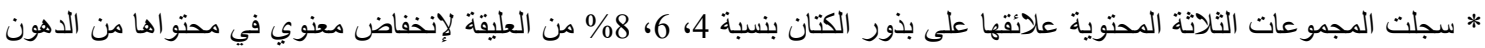
الظهرية ووزن الدهون المحيطة بالجسم و الدهون الثلاثية و الكولستيرول الكلى مقارنة بالمجمو عة الضابطة.

* أدت التغذية بإدخال بذور الكتان فى علائق الار انب بمستوى 6 و 8\% إلى زيادة معنوية في مستويات حمض اللينوليك (اوميجا6) و الالفا

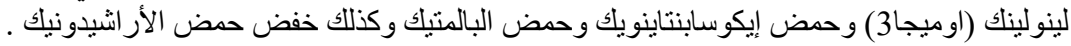
* ادت تغذية بذور الكتان بنسبة 6، 8\% من عليقة الار انب الي زيادة معنوية في الاحماض الدهنية المشبعة .

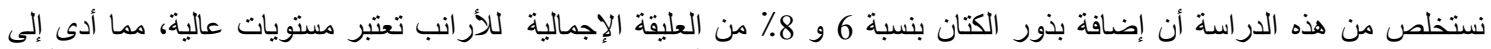

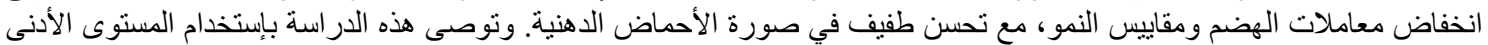

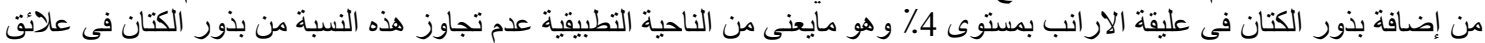
الأر انب.
} 